\title{
Ingestion of guar-gum hydrolysate partially restores calcium absorption in the large intestine lowered by suppression of gastric acid secretion in rats
}

\author{
Hiroshi Hara $^{1 *}$, Takuya Suzuki ${ }^{1}$, Takanori Kasai ${ }^{1}$, Yoritaka Aoyama ${ }^{1}$ and Atsutane Ohta ${ }^{2}$ \\ ${ }^{1}$ Department of Bioscience and Chemistry, Faculty of Agriculture, Hokkaido University, Sapporo 060-8589, Japan \\ ${ }^{2}$ Bioscience Laboratories, Meiji Seika Kaisha, Ltd, Sakado 350-02, Japan
}

(Received 29 May 1998 - Revised 14 October 1998 - Accepted 30 November 1998)

\begin{abstract}
We examined the effects of feeding guar-gum hydrolysate (GGH), a highly fermentable form of dietary fibre with low viscosity, on $\mathrm{Ca}$ absorption in the small and large intestines in rats under conditions in which gastric acid secretion was suppressed by a proton pump inhibitor, omeprazole. We also examined the role of the caecum in influencing these effects. The study was designed in a $2 \times 2 \times 2$ factorial arrangement with two diet (GGH-containing $(50 \mathrm{~g} / \mathrm{kg}$ diet) and GGH-free diets) groups, two injection (omeprazole and vehicle) groups and two operation (sham and caecectomy) groups. Apparent $\mathrm{Ca}$ absorption was lower in rats administered omeprazole $(30 \mathrm{mg} / \mathrm{kg}$ body weight per d) for $8 \mathrm{~d}$ than in rats administered the vehicle. Ingestion of GGH led to partial restoration of $\mathrm{Ca}$ absorption decreased by omeprazole treatment. However, this increment in $\mathrm{Ca}$ absorption was not sufficient to meet requirements because the dietary $\mathrm{Ca}$ level $(3.0 \mathrm{~g} / \mathrm{kg}$ diet $)$ was the minimum requirement for the intact rats. The small increment in $\mathrm{Ca}$ absorption caused by the GGH diet was completely abolished by caecectomy. Soluble Ca pools in the caecal and colonic contents were increased by feeding GGH, and the soluble Ca concentrations were much higher than the $\mathrm{Kt}$ values of the Ca active transport system in the large intestine or the serum $\mathrm{Ca}$ concentration. These findings suggest that $\mathrm{Ca}$ solubilization is not a limiting factor for $\mathrm{Ca}$ absorption in the large intestine. Apparent $\mathrm{Mg}$ absorption was clearly lower in caecectomized rats than in sham-operated rats, and higher in the GGH-fed groups than in the groups fed on the GGH-free diet, even in the case of caecectomized rats. We conclude that $\mathrm{Ca}$ absorption lowered by inhibition of gastric acid secretion is partially restored in rats fed with $\mathrm{GGH}$, but the increment is not sufficient to meet requirements.
\end{abstract}

Calium: Guar gum: Gastric acid

Major dietary sources of $\mathrm{Ca}$ are insoluble salts, and solubilization of these $\mathrm{Ca}$ salts by gastric acid is an essential step for absorption of $\mathrm{Ca}$ via the intestine. Therefore, impairment of gastric acid secretion may be associated with malabsorption of $\mathrm{Ca}$. It is reported that the absorption of insoluble $\mathrm{Ca}$ salts is decreased in patients with achlorhydria (Recker, 1985), and in a rat model of achlorhydria (Mahoney et al. 1975). Previously, we demonstrated that intestinal Ca absorption lowered by partial nephrectomy was fully restored as a result of feeding guar-gum hydrolysate (GGH; Hara et al. 1996), a highly fermentable dietary fibre material with low viscosity (Takahashi et al. 1994). The increase in Ca absorption was dependent on the large intestine (Hara et al. 1996).

Enhancement of caecal fermentation is known to increase caecal absorption of Ca (Demigné et al. 1989; Younes et al. 1996). Karbach \& Feldmeier (1993) showed that the large intestine has a large capacity for $\mathrm{Ca}$ absorption. Furthermore, it was previously demonstrated that feeding of fructooligosaccharides, which are very poorly absorbed, enhanced $\mathrm{Ca}$ absorption via the large intestine upon administration of an insoluble $\mathrm{Ca}$ source into the caecum (Ohta et al. 1997). Ingestion of other fermentable oligosaccharides is also known to increase $\mathrm{Ca}$ absorption (Ammann et al. 1988; Brommage et al. 1993; Chonan \& Watanuki, 1995). Recently, Ohta et al. (1998) showed that Ca absorption lowered by total gastric resection recovered completely on feeding fructo-oligosaccharides. However, the mechanism and role of caecal fermentation in enhancement of $\mathrm{Ca}$ absorption on feeding oligosaccharides have not been clarified. Moreover, the effects of soluble dietary fibre on $\mathrm{Ca}$ absorption under conditions of impairment of gastric acid secretion are not known.

The purpose of the present study was to examine apparent 
$\mathrm{Ca}$ absorption and $\mathrm{Ca}$ dynamics in the small and large intestines after feeding GGH to rats treated with a proton pump inhibitor, omeprazole (Elander et al. 1986), with or without caecectomy. The caecum substantially contributes to large-intestinal fermentation in rats. We also examined apparent $\mathrm{Mg}$ absorption under the same conditions for comparison with $\mathrm{Ca}$ absorption.

\section{Experimental methods}

\section{Animals and diets}

Fifty-eight male Sprague-Dawley rats (Japan SLC, Hamamatsu, Japan), weighing about $100 \mathrm{~g}$, were given free access to deionized water and the semi-purified stock diet shown in Table 1 for an acclimatization period of $5 \mathrm{~d}$, and were divided into two groups, one of thirty-four rats and one of twenty-four rats. Rats of the first group were subjected to caecectomy (CCX group) and rats of the second group were subjected to laparotomy (sham-operated group) under anaesthesia (pentobarbital sodium, $40 \mathrm{mg} / \mathrm{kg}$ body weight; Abbott, North Chicago, IL, USA). After a recovery period (4 d) on the stock diet, the sham and CCX groups were each divided into four sub-groups of eight rats (CCX) and six rats (sham) using a randomized block design based on body weight. Two rats from the CCX group died with operative damage. Two of the sub-groups of each operation group were subcutaneously administered omeprazole $(30 \mathrm{mg} / \mathrm{kg}$ body weight, kindly provided by Astra Japan, Osaka, Japan), and the other two sub-groups were administered its vehicle (PEG 400- $\mathrm{NaHCO}_{3}(10 \mathrm{mM}) ; 1: 1$, v/v). Omeprazole or the vehicle was injected once daily at

Table 1. Composition ( $\mathrm{g} / \mathrm{kg}$ diet) of stock and test diets

\begin{tabular}{lc}
\hline & Test diets* $^{*}$ \\
\hline Casein† & 250 \\
Maize oilł & 50 \\
Mineral mixture (Ca free)§ & 27 \\
Ca carbonate & 7.5 \\
Vitamin mixturell & 10 \\
Granulated vitamin Eף & 1.0 \\
Choline bitartrate & 4.0 \\
Sucrose & to make $1 \mathrm{~kg}$ \\
\hline
\end{tabular}

* The composition of the stock diet was the same as that of the test diet except for the Ca concentration ( $4.5 \mathrm{~g} / \mathrm{kg}$ diet). Guar-gum hydrolysate (GuarFiber, Meiji Seika Kaisha Ltd, Tokyo, Japan; $50 \mathrm{~g} / \mathrm{kg}$ diet) was added to the test diet. Crystalline cellulose (Avicel PH102, Asahi Chemical Industry Co. Ltd, Tokyo, Japan), $50 \mathrm{~g} / \mathrm{kg}$ diet, was added to the test diets with and without guar gum hydrolysate. Both fibre sources were added to the test diets at the expense of the whole diet.

†ALACID; New Zealand Dairy Board, Wellington, New Zealand.

¥ Retinyl palmitate $(7.66 \mu \mathrm{mol} / \mathrm{kg}$ diet $)$ and ergocalciferol $(0.0504 \mu \mathrm{mol} / \mathrm{kg}$ diet $)$ were added to the maize oil. Ergocalciferol was excluded from the test diet used in experiments $2-4$.

$\S$ The mineral mixture was prepared as established by the AIN-76 Workshop held in 1989 (Reeves, 1989), without Ca. It provided (mg/kg diet): P 2997, K 3746, Mg 375, Fe 100, I 0.32, Mn 10.0, Zn 34.7, Cu 6.00, Na 4279, Cl 6542, Se 1.05, Mo 1.00, Cr 0.50, B 0.50, V 0.25, Sn 2.00, As 1.00, Si 20.0, Ni 1.00, F 2.72, Co 0.20 . The Ca concentration in the stock diet was $4.5 \mathrm{~g} / \mathrm{kg}$ diet and that in the test diet was $3.0 \mathrm{~g} / \mathrm{kg}$ diet.

- The vitamin mixture was prepared in accordance with the AIN-76 mixture (American Institute of Nutrition, 1977) except that menadione and L-ascorbic acid were added at $5.81 \mu \mathrm{mol} / \mathrm{kg}$ diet (American Institute of Nutrition, 1980) and $284 \mu \mathrm{mol} / \mathrm{kg}$ diet (Harper, 1959) respectively.

IV Vitamin E granules (Juvela, Eisai Co., Tokyo, Japan) supplied $423 \mu \mathrm{mol}$ all-rac- $\alpha$-tocopheryl acetate $/ \mathrm{kg}$ of diet.
16.00-17.00 hours. From the next day after starting administration of omeprazole or the vehicle, the diet fed to four sub-groups (omeprazole-treated sham and CCX groups) was changed to the test diet containing GGH $(50 \mathrm{~g} / \mathrm{kg}$ diet; GuarFiber, Meiji Seika Kaisha, Ltd, Tokyo, Japan) and the diet fed to the other four sub-groups was changed to the GGH-free test diet. The animals were fed on the test diets for a period of $7 \mathrm{~d}$. In the last $6 \mathrm{~d}$ period, coprophagy was prevented by means of a wire-mesh anal cup as described before (Ohta et al. 1996). Faeces were collected during the last $3 \mathrm{~d}$ to evaluate $\mathrm{Ca}$ and $\mathrm{Mg}$ excretion and apparent absorption of $\mathrm{Ca}$ and $\mathrm{Mg}$. All faeces excreted in the $3 \mathrm{~d}$ period were collected from the anticoprophagy anal cups, and were freeze-dried.

Rats used in the experiment were housed individually in stainless-steel cages with mesh bottoms. The cages were placed in a room with controlled temperature $\left(22-24^{\circ}\right)$, relative humidity (40-60\%) and lighting (lights on: 08.0020.00 hours).

At the end of the experiment, the rats were killed under pentobarbital anaesthesia. The distal half of the small intestine (ileum), caecum and colon were removed immediately without loss of their contents, and their contents were completely removed for further analysis.

GGH is a partial hydrolysate of guar gum, prepared by digestion with $\beta$-1,4-mannanase (EC 3.2.1.25), having an average molecular mass of 15000 , and this material was added to the test diet, as a source of dietary fibre, to give a concentration of $50 \mathrm{~g} / \mathrm{kg}$. Rats were given free access to the test diet and deionized water during the test period. Body weight and food intake were measured every day.

This study was approved by the Hokkaido University Animal Committee, and animals were maintained in accordance with the Hokkaido University guidelines for the care and use of laboratory animals.

\section{Analytical methods}

Freeze-dried faeces were milled. Powdered faecal material (about $70 \mathrm{mg}$ ) was wet-ashed with $5 \mathrm{ml}$ of a mixture of $10 \mathrm{M}$ $\mathrm{HNO}_{3}$ and $2 \cdot 3 \mathrm{M}-\mathrm{HClO}_{4}$ under temperature-controlled conditions, $150^{\circ}$ for the first $30 \mathrm{~min}$ then $200^{\circ}$, taking care to prevent the samples drying out during digestion. The caecal and colonic contents diluted with nine volumes of deionized water, and the ileal contents washed out of the removed segment with $10 \mathrm{ml}$ deionized water, were homogenized by means of a Teflon homogenizer. Amounts of total $\mathrm{Ca}$ in the contents were measured after the sub-sampled homogenate had been wet-ashed in the same way as the faeces. Soluble $\mathrm{Ca}$ was assayed in the supernatant fraction obtained on centrifugation $(30000 \mathrm{~g}$ for $20 \mathrm{~min}$ ) of sub-sampled homogenate. $\mathrm{Ca}$ and $\mathrm{Mg}$ concentrations in the ashed solutions were measured by atomic absorption spectrophotometry (AA6400F; Shimadzu, Kyoto, Japan) after adequate dilution with water.

\section{Calculations and statistical analysis}

Apparent absorption of $\mathrm{Ca}$ or $\mathrm{Mg}$ was calculated as follows: apparent $\mathrm{Ca}(\mathrm{Mg})$ absorption $(\%)=100 \times($ total $\mathrm{Ca}(\mathrm{Mg})$ intake - faecal $\mathrm{Ca}(\mathrm{Mg})$ excretion)/total $\mathrm{Ca}(\mathrm{Mg})$ intake. 
Weights of caecal and colonic contents were evaluated as the differences between weights of the caecum and colon with their contents and their washed wall weights.

The results were analysed by three-way ANOVA (caecectomy, omeprazole and GGH). Duncan's multiple range test was used to determine whether mean values were significantly different $(P<0 \cdot 05)$. These statistical analyses were done by the general linear models procedure of the Statistical Analysis Systems program (version 6.07 SAS Institute Inc., Cary, NC, USA).

\section{Results}

Table 2 shows the changes in body weight and food intake. Final body weight was not changed by caecectomy, omeprazole treatment or feeding GGH, however, body-weight gain was influenced by omeprazole treatment as indicated by the results of ANOVA.

As shown in Fig. 1(a), apparent $\mathrm{Ca}$ absorption in the omeprazole-treated groups was lower than that in the nontreated groups of sham and CCX rats. In the omeprazoletreated groups, the absorption rate in the rats fed on the GGH-containing diet was significantly higher than that in the sham rats fed on the GGH-free diet, but not in the CCX rats. The levels of $\mathrm{Ca}$ absorption in $\mathrm{CCX}$ rats were also lower than those in sham rats, except for the group treated with omeprazole and fed on the GGH-free diet.

$\mathrm{Mg}$ absorption rates (Fig. 1(b)) were significantly higher in the GGH-fed groups than in the groups fed on the GGHfree diet, except for the omeprazole-treated sham rats. The levels of $\mathrm{Mg}$ absorption in all CCX groups were much lower than those in all sham groups. Omeprazole treatment did not influence $\mathrm{Mg}$ absorption.
The wet weights of the caecal contents in sham rats and the colonic contents in CCX rats were greater in the GGH-fed groups than in the groups fed on the GGH-free diet (Table 3 ). In the sham rats, the wet weight of the colonic contents was significantly higher in the GGH-fed group than in the group fed on the GGH-free diet in the rats administered omeprazole, but not in the rats administered the vehicle. Changes in faecal dry weight during the $3 \mathrm{~d}$ period were very similar to those observed for the colonic contents.

As shown in Table 4, the total Ca pools in the caecal and colonic contents of sham rats were much larger in the omeprazole-treated groups than in the vehicle-treated groups. In contrast, the soluble $\mathrm{Ca}$ pool in the sham rats was not changed by omeprazole treatment. In both the omeprazole- and vehicle-treated groups, the caecal soluble $\mathrm{Ca}$ pools were larger in the GGH-fed rats than in the rats fed on the GGH-free diet. In the sham rats, changes in colonic total and soluble Ca pools were similar to those in the caecal Ca pools. In CCX rats, the total colonic Ca pools were larger than in the sham rats, especially in the omeprazole-treated groups. As indicated by the results of ANOVA, the colonic total $\mathrm{Ca}$ and soluble $\mathrm{Ca}$ pools were affected by caecectomy, omeprazole treatment and GGH feeding. The ileal soluble $\mathrm{Ca}$ pool was smaller in the omeprazole-treated groups than in the sham groups.

As shown in Table 5, the $\mathrm{pH}$ of the caecal contents in the omeprazole- and vehicle-treated sham groups was lower in rats fed on the GGH-containing diet than in rats fed on the GGH-free diet, and, among the GGH-fed rats, the $\mathrm{pH}$ value in the omeprazole-treated group was higher than that in the vehicle-treated group. Changes in the $\mathrm{pH}$ of the colonic contents were similar to those observed for the caecal

Table 2. Initial and final body weights $(\mathrm{g})$, and changes in body weight and food intake $(\mathrm{g} / \mathrm{d})$ of rats after administration of omeprazole (OM), feeding of guar-gum hydrolysate (GGH) diet and caecectomy or sham operation*

(Mean values with their standard errors for six rats in the sham groups and eight rats in the caecectomized groups)

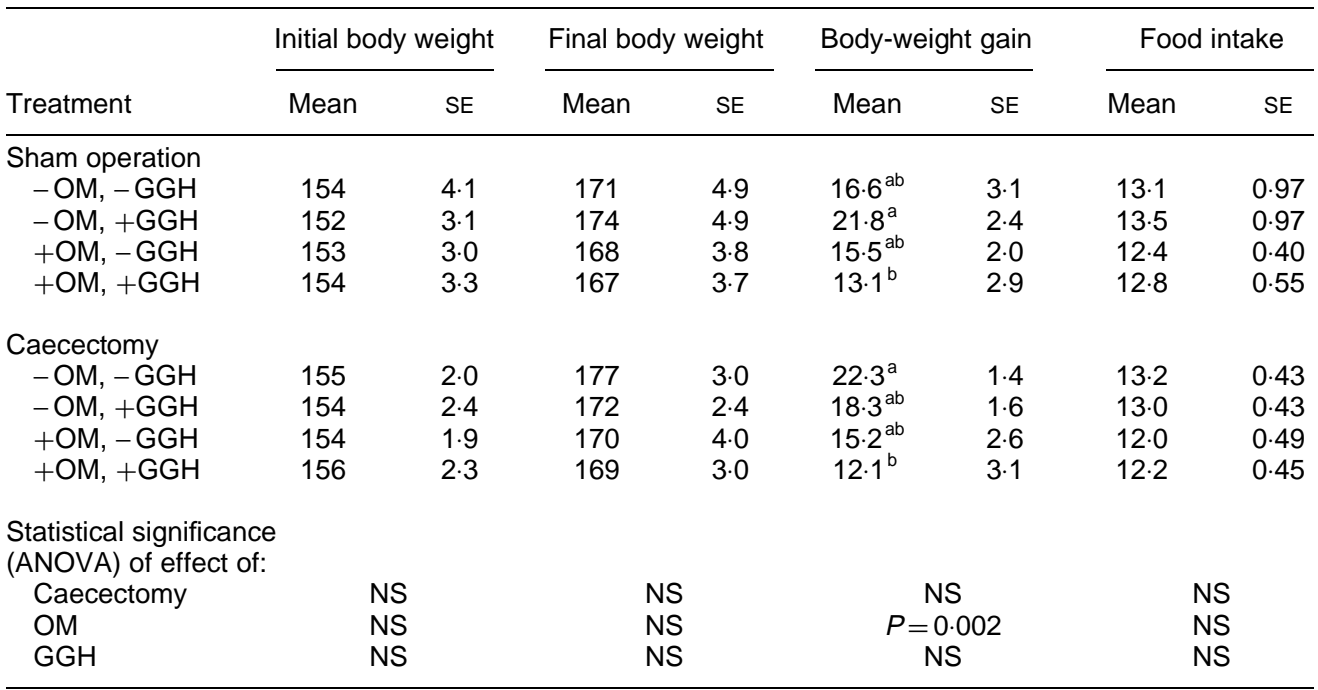

\footnotetext{
${ }^{a, b}$ Mean values within a column not sharing a common superscript letter were significantly different, $P<0.05$ (Duncan's multiple range test).

${ }^{*}$ For details of diets and procedures, see Table 1 and pp. 316-317.
} 

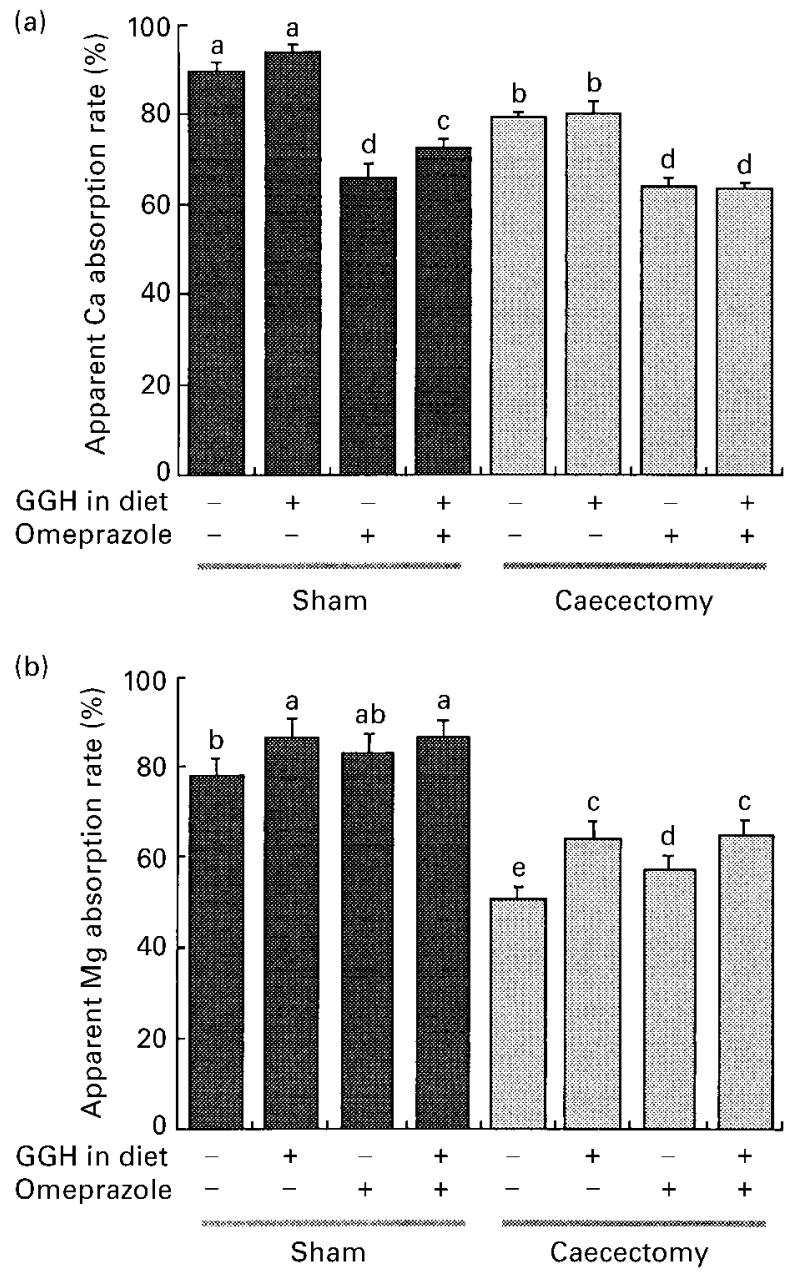

Fig. 1. Changes in (a) apparent calcium absorption and (b) apparent magnesium absorption of sham-operated or caecectomized rats fed on a diet containing guar-gum hydrolysate (GGH) with or without omeprazole treatment $(30 \mathrm{mg} / \mathrm{kg}$ body weight per d). All values are means with their standard errors for six rats in the sham groups and eight rats in the caecectomized groups. $P$ values estimated by threeway ANOVA were: panel (a), $<0.001$ for $\mathrm{GGH},<0.001$ for omeprazole treatment and 0.010 for caecectomy; and panel (b), $<0.001$ for GGH, not significant for omeprazole treatment and $<0.001$ for caecectomy. Mean values not sharing a common letter were significantly different between diet groups $(P<0.05)$ according to Duncan's multiple range test.

contents in sham rats. In CCX rats, the $\mathrm{pH}$ of the colonic contents was lower in the GGH group than in the group fed on the GGH-free diet. Omeprazole treatment did not influence the $\mathrm{pH}$ of the colonic contents in CCX rats.

\section{Discussion}

We studied the effects of feeding GGH on intestinal Ca absorption in rats with gastric acid secretion suppressed by omeprazole treatment, and examined the involvement of fermentation in the large intestine in influencing these effects. Apparent $\mathrm{Ca}$ absorption was decreased by $25 \%$ as a result of omeprazole treatment. The lowered levels of $\mathrm{Ca}$ absorption were partially restored on feeding GGH, however, the increment obtained through GGH feeding was completely abolished in CCX rats. These results show that the large intestine is responsible for the small increment in $\mathrm{Ca}$ absorption lowered by suppression of gastric acid secretion. It is unlikely that this dietary fibre affects smallintestinal $\mathrm{Ca}$ absorption because GGH is a dietary fibre with very low viscosity. The small increase in apparent $\mathrm{Ca}$ absorption observed may be associated with the caecal fermentation of GGH. Caecal fermentation products, short-chain fatty acids, are known to enhance intestinal $\mathrm{Ca}$ absorption (Lutz \& Scharrer, 1991; Trinidad et al. 1996)

Caecectomy suppressed fermentation and degradation of GGH. The observation that faecal excretion increased as a result of feeding GGH in CCX rats, but not in sham rats (Table 3) indicates the suppression of fermentation of this fibre. The amount of GGH ingested by each rat was approximately $2 \mathrm{~g}$ in a $3 \mathrm{~d}$ period (calculated from Table 2 ), and the increase in faecal dry weight in this $3 \mathrm{~d}$ period was about $1 \mathrm{~g}$ as a result of feeding GGH. These results show that half of the ingested GGH was excreted by the CCX rats. This estimation reveals that a considerable amount of ingested GGH was fermented in the colon of the CCX rats, and our finding that the $\mathrm{pH}$ of the colonic contents was lowered in CCX rats (Table 5) supports this conclusion. However, as described earlier, caecectomy abolished the enhancement of $\mathrm{Ca}$ absorption completely. Furthermore, GGH feeding substantially increased the amount of soluble $\mathrm{Ca}$ in the colon in $\mathrm{CCX}$ and vehicletreated rats; however, the level of $\mathrm{Ca}$ absorption did not change.

The colon has an extensive capacity for $\mathrm{Ca}$ absorption (Ammann et al. 1986; Pitcher \& Buffenstein, 1994). It is reported that the $\mathrm{Ca}$ concentration at half $\mathrm{V}_{\mathrm{MAX}}(K \mathrm{t})$ for active $\mathrm{Ca}$ transport are $0.94 \mathrm{mmol} / \mathrm{l}$ (Karbach \& Rummel, 1987) and $1.6 \mathrm{mmol} / \mathrm{l}$ (Favus et al. 1981) in the ascending and descending colon respectively. We did not measure the amount of water in the colonic contents. It is usually approximately $50 \%$ (Ohta et al. 1995). From the values obtained for the soluble $\mathrm{Ca}$ pool, shown in Table 4, the concentration is estimated as $15-35 \mathrm{mmol} / \mathrm{l}$, which is much higher than $K \mathrm{t}$ values for colonic $\mathrm{Ca}$ absorption described earlier, and also much higher than the serum $\mathrm{Ca}$ concentration (about $2.5 \mathrm{mmol} / \mathrm{l} ; \mathrm{H}$. Hara, unpublished results). These results indicate that soluble $\mathrm{Ca}$ concentration in the colon is sufficiently high for transcellular and paracellular absorption. Ohta et al. (1995) showed that colonic absorption of Ca increased as a result of feeding highly fermentable oligosaccharides to intact rats. Furthermore, the level of dietary $\mathrm{Ca}$ in the present study was $3.0 \mathrm{~g} / \mathrm{kg}$ diet, which is the minimum requirement for intact rats as shown in the previous study (Hara et al. 1996). In rats with lowered Ca absorption (groups other than the sham group not treated with omeprazole), the $\mathrm{Ca}$ levels are insufficient to meet requirements and these rats need to absorb more $\mathrm{Ca}$. Our findings suggest that solubilization of $\mathrm{Ca}$ is not a ratelimiting step for $\mathrm{Ca}$ absorption in the colon. Other factors, for example absorptive activity in the large intestine, may play a crucial role in $\mathrm{Ca}$ absorption.

As in previous observations concerning partially nephrectomized rats, $\mathrm{Ca}$ absorption was decreased to an extent comparable with that in omeprazole-treated rats. The lowered levels of $\mathrm{Ca}$ absorption resulting from nephrectomy 
Table 3. Changes in weight of the caecal and colonic contents (g wet weight/rat), and excreted faeces (g DM/3 d) of rats after administration of omeprazole (OM), feeding of guar-gum hydrolysate $(\mathrm{GGH})$ diet and caecectomy or sham operation*

(Mean values with their standard errors for six rats in the sham groups and eight rats in the caecectomized groups)

\begin{tabular}{|c|c|c|c|c|c|c|}
\hline \multirow[b]{2}{*}{ Treatment } & \multicolumn{2}{|c|}{ Caecal content } & \multicolumn{2}{|c|}{ Colonic content } & \multicolumn{2}{|c|}{ Faeces } \\
\hline & Mean & SE & Mean & SE & Mean & SE \\
\hline $\begin{array}{r}\text { Sham operation } \\
\text {-OM, - GGH } \\
\text {-OM, +GGH } \\
\text { +OM, - GGH } \\
\text { +OM, + } \mathrm{GGH}\end{array}$ & $\begin{array}{l}1.36^{b} \\
3.75^{a} \\
2 \cdot 00^{b} \\
3.04^{a}\end{array}$ & $\begin{array}{l}0.11 \\
0.35 \\
0.19 \\
0.28\end{array}$ & $\begin{array}{l}0.512^{\text {de }} \\
0.743^{\text {cd }} \\
0.412^{\mathrm{e}} \\
0.683^{\text {cd }}\end{array}$ & $\begin{array}{l}0.042 \\
0.132 \\
0.069 \\
0.136\end{array}$ & $\begin{array}{l}2 \cdot 79^{b c} \\
2 \cdot 83^{b c} \\
2 \cdot 37^{c} \\
2 \cdot 86^{b c}\end{array}$ & $\begin{array}{l}0.45 \\
0.20 \\
0.10 \\
0.11\end{array}$ \\
\hline $\begin{array}{l}\text { Caecectomy } \\
\text {-OM, - GGH } \\
\text {-OM, +GGH } \\
\text { +OM, - GGH } \\
\text { +OM, +GGH }\end{array}$ & & & $\begin{array}{l}0.869^{c} \\
1.622^{a} \\
0.850^{c} \\
1.317^{b}\end{array}$ & $\begin{array}{l}0.136 \\
0.074 \\
0.071 \\
0.082\end{array}$ & $\begin{array}{l}3 \cdot 10^{\mathrm{b}} \\
4 \cdot 14^{\mathrm{a}} \\
2 \cdot 91^{\mathrm{bc}} \\
4 \cdot 11^{\mathrm{a}}\end{array}$ & $\begin{array}{l}0.12 \\
0.21 \\
0.12 \\
0.19\end{array}$ \\
\hline
\end{tabular}

Statistical significance

(ANOVA) of effect of:

$\begin{array}{lccc}\text { Caecectomy } & - & P<0.001 & P<0.001 \\ \text { OM } & \text { NS } & \text { NS } & \text { NS } \\ \text { GGH } & P<0.001 & P<0.001 & P<0.001\end{array}$

a,b,c,d,e Mean values within a column not sharing a common superscript letter were significantly different, $P<0.05$ (Duncan's multiple range test).

${ }^{*}$ For details of diets and procedures, see Table 1 and pp. 316-317.

recovered to the level observed in intact rats on feeding a diet containing the same level of GGH as in the diet used in the present study. In contrast, $\mathrm{Ca}$ absorption in the omeprazole-treated rats was increased significantly but insufficiently. Lowered $\mathrm{pH}$ of the caecal contents (Table 5) and no increase in faecal excretion (Table 3) in GGH-fed rats compared with rats fed on the GGH-free diet show that ingested GGH was fermented almost completely in the large intestine in the sham rats. The concentration of soluble $\mathrm{Ca}$ in the caecal contents was $6-10 \mathrm{mmol} / \mathrm{l}$, as calculated from the data in Table 4, and the amount of water in the caecal contents was approximately $70 \%$ (the results of a separate experiment). The solubilization of $\mathrm{Ca}$ in the caecal contents may not be rate limiting for caecal $\mathrm{Ca}$ absorption as in the

Table 4. Total Ca pool and soluble Ca pool ( $\mathrm{mg} / \mathrm{rat})$ in the caecal colonic contents of rats after administration of omeprazole (OM), feeding of guargum hydrolysate (GGH) diet and caecectomy or sham operation*

(Mean values with their standard errors for six rats in the sham groups and eight rats in the caecectomized groups)

\begin{tabular}{|c|c|c|c|c|c|c|c|c|c|c|c|c|}
\hline & \multicolumn{4}{|c|}{ Ileal contents } & \multicolumn{4}{|c|}{ Caecal contents } & \multicolumn{4}{|c|}{ Colonic contents } \\
\hline & \multicolumn{2}{|c|}{ Total Ca } & \multicolumn{2}{|c|}{ Soluble $\mathrm{Ca}$} & \multicolumn{2}{|c|}{ Total Ca } & \multicolumn{2}{|c|}{ Soluble Ca } & \multicolumn{2}{|c|}{ Total Ca } & \multicolumn{2}{|c|}{ Soluble Ca } \\
\hline & Mean & SE & Mean & SE & Mean & SE & Mean & SE & Mean & SE & Mean & SE \\
\hline $\begin{array}{r}\text { Sham operation } \\
\text { - OM, - GGH } \\
\text {-OM, +GGH } \\
\text { +OM, - GGH } \\
\text { +OM, +GGH }\end{array}$ & $\begin{array}{l}0.574^{\mathrm{ab}} \\
0.507^{\mathrm{abc}} \\
0.499^{\mathrm{abc}} \\
0.336^{\mathrm{bc}}\end{array}$ & $\begin{array}{l}0.111 \\
0.112 \\
0.117 \\
0.065\end{array}$ & $\begin{array}{l}0.363^{\mathrm{ab}} \\
0.376^{\mathrm{a}} \\
0.182^{\mathrm{bc}} \\
0.187^{\mathrm{bc}}\end{array}$ & $\begin{array}{l}0.086 \\
0.080 \\
0.024 \\
0.054\end{array}$ & $\begin{array}{r}2 \cdot 14^{\mathrm{b}} \\
3 \cdot 06^{\mathrm{b}} \\
10 \cdot 80^{\mathrm{a}} \\
8 \cdot 78^{\mathrm{a}}\end{array}$ & $\begin{array}{l}0.514 \\
0.877 \\
2.28 \\
0.660\end{array}$ & $\begin{array}{l}0.280^{b} \\
1.030^{a} \\
0.343^{b} \\
0.771^{a}\end{array}$ & $\begin{array}{l}0.043 \\
0.296 \\
0.033 \\
0.195\end{array}$ & $\begin{array}{l}0.990^{\text {de }} \\
0.781^{\mathrm{e}} \\
2.790^{\mathrm{abc}} \\
2.880^{\mathrm{ab}}\end{array}$ & $\begin{array}{l}0.173 \\
0.225 \\
0.706 \\
0.604\end{array}$ & $\begin{array}{l}0.226^{c} \\
0.309^{c} \\
0.201^{c} \\
0.369^{b c}\end{array}$ & $\begin{array}{l}0.034 \\
0.087 \\
0.015 \\
0.039\end{array}$ \\
\hline $\begin{array}{l}\text { Caecectomy } \\
\text { - OM, - GGH } \\
\text {-OM, +GGH } \\
\text { +OM, - GGH } \\
\text { +OM, +GGH }\end{array}$ & $\begin{array}{l}0.658^{a} \\
0.589^{a b} \\
0.323^{b c} \\
0.248^{c}\end{array}$ & $\begin{array}{l}0.140 \\
0.096 \\
0.072 \\
0.053\end{array}$ & $\begin{array}{l}0.338^{a b c} \\
0.380^{a} \\
0.193^{c} \\
0.176^{c}\end{array}$ & $\begin{array}{l}0.060 \\
0.052 \\
0.032 \\
0.041\end{array}$ & & - & & - & $\begin{array}{l}2 \cdot 53^{\mathrm{bc}} \\
2 \cdot 28^{\mathrm{bc}} \\
3 \cdot 77^{\mathrm{a}} \\
1 \cdot 77^{\mathrm{cd}}\end{array}$ & $\begin{array}{l}0.350 \\
0.296 \\
0.280 \\
0.261\end{array}$ & $\begin{array}{l}0.533^{b} \\
1.120^{a} \\
0.249^{c} \\
0.372^{b c}\end{array}$ & $\begin{array}{l}0.065 \\
0.121 \\
0.051 \\
0.061\end{array}$ \\
\hline $\begin{array}{l}\text { Statistical signific } \\
\text { (ANOVA) of effec } \\
\text { Caecectomy } \\
\text { OM } \\
\text { GGH }\end{array}$ & $P=$ & & $P<$ & $\begin{array}{l}S \\
.001 \\
S\end{array}$ & $P<$ & IS & & $\begin{array}{l}S \\
.004\end{array}$ & $\begin{array}{l}P=0 \\
P<0 \\
P=0\end{array}$ & $\begin{array}{l}034 \\
001 \\
010\end{array}$ & $\begin{array}{l}P< \\
P< \\
P<\end{array}$ & $\begin{array}{l}0.001 \\
0.001 \\
0.001\end{array}$ \\
\hline
\end{tabular}

a,b,c,d,e Mean values within a column not sharing a common superscript letter were significantly different, $P<0.05$ (Duncan's multiple range test).

For details of diets and procesures, see Table 1 and pp. 316-317. 
Table 5. Changes in the $\mathrm{pH}$ of the caecal and colonic contents of rats after administration of omeprazole (OM, $30 \mathrm{mg} / \mathrm{kg}$ per d), feeding of guar-gum hydrolysate (GGH) diet and caecectomy or sham operation*

(Mean values with their standard errors for six rats in the sham groups and eight rats in the caecectomized groups)

\begin{tabular}{|c|c|c|c|c|}
\hline \multirow[b]{2}{*}{ Treatment } & \multicolumn{2}{|c|}{$\mathrm{pH}$ of the caecal contents } & \multicolumn{2}{|c|}{$\mathrm{pH}$ of the colonic contents } \\
\hline & Mean & SE & Mean & SE \\
\hline \multicolumn{5}{|l|}{ Sham operation } \\
\hline$-\mathrm{OM},-\mathrm{GGH}$ & $7 \cdot 17^{\mathrm{a}}$ & 0.18 & $7 \cdot 04^{a}$ & 0.10 \\
\hline$-\mathrm{OM},+\mathrm{GGH}$ & $5 \cdot 64^{c}$ & 0.09 & $6 \cdot 05^{d}$ & 0.13 \\
\hline$+\mathrm{OM},-\mathrm{GGH}$ & $6 \cdot 83^{a}$ & 0.04 & $6 \cdot 97^{a}$ & 0.04 \\
\hline$+\mathrm{OM},+\mathrm{GGH}$ & $6 \cdot 12^{b}$ & 0.13 & $6 \cdot 50^{b}$ & 0.06 \\
\hline \multicolumn{5}{|l|}{ Caecectomy } \\
\hline$-\mathrm{OM},-\mathrm{GGH}$ & & & $7 \cdot 05^{a}$ & 0.03 \\
\hline$-\mathrm{OM},+\mathrm{GGH}$ & & & $6 \cdot 25^{c}$ & 0.09 \\
\hline$+\mathrm{OM},-\mathrm{GGH}$ & & & $6.98^{a}$ & 0.04 \\
\hline$+\mathrm{OM},+\mathrm{GGH}$ & & & $6 \cdot 27^{c}$ & $0 \cdot 10$ \\
\hline \multicolumn{5}{|c|}{ Statistical significance } \\
\hline \multicolumn{2}{|c|}{$\begin{array}{l}\text { (ANOVA) of effect of: } \\
\text { Caecectomv }\end{array}$} & - & \multicolumn{2}{|c|}{ NS } \\
\hline OM & & & & \\
\hline GGH & \multicolumn{2}{|c|}{$P<0.001$} & \multicolumn{2}{|c|}{$P<0.001$} \\
\hline
\end{tabular}

case of colonic absorption described earlier. Feeding of GGH lowered the $\mathrm{pH}$ and increased the soluble $\mathrm{Ca}$ pool in the caecal contents; however, these changes were not associated with sufficient recovery of $\mathrm{Ca}$ absorption lowered by omeprazole treatment even under conditions of mild $\mathrm{Ca}$ deficiency. Karbach \& Feldmeier (1993) showed that the caecum has the highest capacity for $\mathrm{Ca}$ absorption. In mole rats (Cryptomys hottentotus), it has been shown that the highest capacity for active uptake of $\mathrm{Ca}$ is in the caecum (Pitcher \& Buffenstein, 1994). Possibly omeprazole itself or some other factor in omeprazole-treated rats, prevents the increase in $\mathrm{Ca}$ absorption in the large intestine.

The soluble $\mathrm{Ca}$ pool in the ileal contents clearly decreased, while the total $\mathrm{Ca}$ pool in the caecal contents substantially increased as a result of omeprazole treatment (Table 4). These results demonstrate that suppression of $\mathrm{Ca}$ solubilization and a decrease in $\mathrm{Ca}$ absorption in the small intestine occur in omeprazole-treated rats. The dose of omeprazole used in the present study was rather high, and gastric acid secretion is suppressed for $24 \mathrm{~h}$ by this dose of omeprazole (Segawa et al. 1987; Seensalu et al. 1990). The results concerning ileal levels of soluble and total $\mathrm{Ca}$ show that a considerable amount of $\mathrm{Ca}$ salt was solubilized in the small intestine even in rats treated with omeprazole. Factors other than gastric acid may contribute to the solubilization of $\mathrm{Ca}$ salts in the proximal intestine.

$\mathrm{Mg}$ absorption was decreased as a result of caecectomy in both the omeprazole-treated and non-treated rats. This finding indicates that the caecum and the colon substantially contribute to $\mathrm{Mg}$ absorption, and agrees with reports indicating that the predominant site of $\mathrm{Mg}$ absorption is the large intestine (Chutkow, 1964, 1966). Also, in the CCX rats, GGH feeding slightly but significantly enhanced $\mathrm{Mg}$ absorption, which reveals that colonic $\mathrm{Mg}$ absorption is increased in rats fed on GGH. These observations show that the large intestine contributes to $\mathrm{Mg}$ absorption more than to $\mathrm{Ca}$ absorption, especially in the case of the colon. This result agrees with our previous report (Ohta et al. 1995). Omeprazole treatment did not influence $\mathrm{Mg}$ absorption because we used a soluble $\mathrm{Mg}$ salt $\left(\mathrm{MgSO}_{4}\right)$ in the test diets.

Although the present study showed that ingestion of a low-viscosity highly fermentable dietary fibre increased $\mathrm{Ca}$ absorption, this did not fully restore the insoluble $\mathrm{Ca}$ absorption impaired by suppression of gastric acid secretion. This increment of $\mathrm{Ca}$ absorption may be beneficial for patients with achlorhydria or patients with gastric ulcer using a proton pump inhibitor because $\mathrm{Ca}$ absorption from insoluble dietary sources may decrease greatly in these patients as shown in our experiment using a rat model. The present study also showed that the large intestine is responsible for $\mathrm{Mg}$ absorption, which indicates an increase in the incidence of $\mathrm{Mg}$ deficiency in patients with a resected large intestine.

\section{References}

American Institute of Nutrition (1977) Report of the American Institute of Nutrition ad hoc committee on standards for nutritional studies. Journal of Nutrition 107, 1340-1348.

American Institute of Nutrition (1980) Second report of the ad hoc committee on standards for nutritional studies. Journal of Nutrition 110, 1726.

Ammann P, Rizzoli R \& Fleisch H (1986) Calcium absorption in rat large intestine in vivo: availability of dietary calcium. American Journal of Physiology 251, G14-G18.

Ammann P, Rizzoli R \& Fleisch H (1988) Influence of the disaccharide lactitol on intestinal absorption and body retention of calcium in rats. Journal of Nutrition 118, 793-795.

Brommage R, Binacua C, Antille S \& Carrie AL (1993) Intestinal 
calcium absorption in rats is stimulated by dietary lactulose and other resistant sugars. Journal of Nutrition 123, 2186-2194.

Chonan O \& Watanuki M (1995) Effect of galactooligosaccharides on calcium absorption in rats. Journal of Nutritional Science and Vitaminology 41, 95-104.

Chutkow JG (1964) Sites of magnesium absorption and excretion in the intestinal tract of the rat. Journal of Laboratory and Clinical Medicine 63, 71-79.

Chutkow JG (1966) Effect of magnesium deficiency on location of the intestinal absorption of magnesium in rats. Proceedings of the Society for Experimental Biology and Medicine 123, 836840.

Demigné C, Levrat M \& Rémésy C (1989) Effects of feeding fermentable carbohydrates on the cecal concentrations of minerals and their fluxes between the cecum and blood plasma in the rat. Journal of Nutrition 119, 1625-1630.

Elander B, Fellenius E, Leth R, Olbe L \& Wallmark B (1986) Inhibitory action of omeprazole on acid formation in gastric glands and on $\mathrm{H}^{+}, \mathrm{K}^{+}$-ATPase isolated from human gastric mucosa. Scandinavian Journal of Gastroenterology 21, 268272.

Favus MJ, Kathpalia SC \& Coe FL (1981) Kinetic characteristics of calcium absorption and secretion by rat colon. American Journal of Physiology 240, G350-G354.

Hara H, Nagata M, Ohta A \& Kasai T (1996) Increases in calcium absorption with ingestion of soluble dietary fibre, guar-gum hydrolysate, depend on the caecum in partially nephrectomized and normal rats. British Journal of Nutrition 76, 773-784.

Harper AE (1959) Amino acid balance and imbalance. 1. Dietary level of protein and amino acid imbalance. Journal of Nutrition 68, 405-418.

Karbach U \& Feldmeier H (1993) The cecum is the site with the highest calcium absorption in rat intestine. Digestive Diseases and Sciences 38, 1815-1824.

Karbach U \& Rummel W (1987) Calcium transport across the colon ascendens and the influence of 1,25-dihydroxyvitamin D3 and dexamethasone. European Journal of Clinical Investigation 17, 368-374.

Lutz T \& Scharrer E (1991) Effect of short-chain fatty acids on calcium absorption by the rat colon. Experimental Physiology 76, 615-618.

Mahoney AW, Holbrook RS \& Hendricks DG (1975) Effects of calcium solubility on absorption by rats with induced achlorhydria. Nutrition and Metabolism 18, 310-317.
Ohta A, Baba S, Ohtsuki M, Taguchi A, Adachi T \& Hara H (1996) Prevention of coprophagy modifies magnesium absorption in rats fed with fructo-oligosaccharides. British Journal of Nutrition 75, 775-784.

Ohta A, Baba S, Ohtsuki M, Takizawa T, Adachi T \& Hara H (1997) In vivo absorption of calcium carbonate and magnesium oxide from the large intestine in rats. Journal of Nutritional Science and Vitaminology 43, 35-46.

Ohta A, Ohtsuki M, Baba S, Adachi T, Sakata T \& Sakaguchi E (1995) Calcium and magnesium absorption from the colon and rectum are increased in rats fed fructooligosaccharides. Journal of Nutrition 125, 2417-2424.

Ohta A, Ohtsuki M, Hosono A, Adachi T, Hara H \& Sakata T (1998) Dietary fructooligosaccharides prevent osteopenia after gastrectomy in rats. Journal of Nutrition 128, 106-110.

Pitcher T \& Buffenstein R (1994) Passive uptake in the small intestine and active uptake in the hindgut contribute to the highly efficient mineral metabolism of the common mole-rat, Cryptomys hottentotus. British Journal of Nutrition 71, 573582.

Recker RR (1985) Calcium absorption and achlorhydria. New England Journal of Medicine 313, 70-73.

Reeves PG (1989) AIN-76 diet: should we change the formulation? Journal of Nutrition 119, 1081-1082.

Seensalu R, Girma K, Romell B \& Nilsson G (1990) Time course of inhibition of gastric acid secretion by omeprazole and ranitidine in gastric fistula rats. European Journal of Pharmacology 180, 145-152.

Segawa K, Nakazawa S, Tsukamoto Y, Chujoh C, Yamao K \& Hase $S$ (1987) Effect of omeprazole on gastric acid secretion in rat: evaluation of dose, duration of effect, and route of administration. Gastroenterologia Japonica 22, 413-418.

Takahashi H, Yang SI, Kim M \& Yamamoto T (1994) Protein and energy utilization of growing rats fed on the diets containing intact or partially hydrolyzed guar gum. Comparative Biochemistry and Physiology 107A, 255-260.

Trinidad TP, Wolever TM \& Thompson LU (1996) Effect of acetate and propionate on calcium absorption from the rectum and distal colon of humans. American Journal of Clinical Nutrition 63, 574-578.

Younes H, Demigné C \& Rémésy C (1996) Acidic fermentation in the caecum increases absorption of calcium and magnesium in the large intestine of the rat. British Journal of Nutrition 75, 301-314. 